\title{
衙撃破壊しん性試験における動的応力拡大係数の数值計算*1 \\ Numerical Computation of Dynamic Stress Intensity Factor for \\ Impact Fracture Toughness Test
}

\author{
中 野 元 博*2 岸田敬 三*2 \\ Motohiro NAKANO and Keizo KISHIDA
}

Key Words : Fracture, Stress Intensity Factor, Impact Test, Finite Element Method

\begin{abstract}
Consideration of inertia effect is important to estimate the stress intensity factor for impact fracture toughness test. In the present paper the dynamic stress intensity factor $K(t)$ is calculated from $K(t)=\alpha(t) \cdot K^{\text {stat }}$, where $\alpha(t)$ is the impact response function and $K^{\text {stat }}$ is the corresponding static value. The $\alpha(t)$ is computed by superimposing the step response function $h(t)$. The $h(t)$ for the crack, subjected to step load, is evaluated using the finite element method. The numerical computation of $K(t)$ is carried out for the experiment introduced by Costin et al. The results indicate the good applicability of this method for the determination of the impact fracture toughness $K_{\text {Id. }}$.
\end{abstract}

\section{1. 序論}

1950 年代に誕生した破壊力学は，すでに静的な弾 性問題に対する体系化を完了した，線形破壊力学に基 ういて材料の静的負荷下の破壊抵抗を求める平面ひず み破懐しん性 $K_{\mathrm{Ic}}$ 試験法は，1970 年にASTMで最初 に規格化された。この $K_{\mathrm{Ic}}$ による強度評価は，現在で も種々の構造物の設計・保守へ適用されているが，そ の負荷速度は ASTM 規格（E 399） ${ }^{1)}$ で定めた $K_{\mathrm{Ic}}$ 試験 の負荷速度の上限 $2.75 \mathrm{MPa} \sqrt{\mathrm{m}} / \mathrm{s}$ を超えない䈯囲に 限定される，近年，高速負荷に対する強度評価が要求 されるようになり，ASTM E 399-83で破壊開始時 間 $(t)$ が $1 \mathrm{~ms}$ 以上であることなどの特別な必要条件 の規定（Annex A 7) を設けてより高い負荷速度にお ける $K_{\mathrm{Ic}}(t)$ 〈高速負荷平面Uずみ破壊じん性〕の湘定が 静的試験と同様に実施できるように改訂された．この 笛囲の高速負荷の下でき裂を含む部材は，まだ静的と ほ浔同じような変形を行っていると考えてよいが，さ

\footnotetext{
*1 昭和 62 年 8 月 26 日原稿受理

*2 大阪大学工学部
}

らに速い衝酘荷重下では，物体の慣性力の影暳が大き く，変形は静的な場合と異なってしまう。したがっ て，衝撃負荷に対する強度評価には，き裂を含む部材 の動的解析が不可欠であり．衝擊破壊じん性 $K_{\mathrm{Id}}$ の測 定においても動的応力係数 $K(t)$ を正しく評価できる 試験法を開発する必要がある。

衝撃破買は工学的に重要な問題であり．予き裂試験 片を用いた計装化シャルピ試験等 $\left.{ }^{2}\right)$ 多くの研究がこれ までに行われてきた。しかし，衝撃破壊じん性 $K_{\text {Id }}$ 試 験は, 衝擊荷重の正確な計測，動的応力拡大係数の計 算，破壊開始点の検出という実験的に困難な問題を有 しているため,いまだ確立されていない，1977年に Costin ら"が提案したホプキンソン棒方式の衝撃破壊 じん性試験は，予き裂に入射する応力波を測定するこ とにより衝撃荷重の正確な計測を可能にした点で優れ ているが，応力拡大係数の算出に静的な $K^{\text {stat }} の$ 評価 式を用いた点，および破壊開始点を静的と同じ規準で 決定した点で，正しい衝撃破壊じん性 $K_{\mathrm{Id}}$ の測定法と はいえない。また，衝撃三点曲げ $K_{\mathrm{Id}}$ 試験において湘 定される衝擊荷重から，単純支持された試験片の曲げ 振動を考虑して $K(t)$ を簡便に評価する方法を $\mathrm{Ki}$ shimotoら“が提案しているが，実際には試験片が支 点から離れる状態が起こりうる゙'ため， $K(t)$ を高精度 に計算する上で問題を残している.

Costin ら"の実験のように予き裂に応力波が入射し た場合，応力波はき裂面で反射され，き裂先端では回 折されて、き裂先端近傍に特異な応力・変位場を発達 させる.この動的な応力・変位場の分布形（き裂先端 を原点とする極座標で表した $r と$ に対する関数形) は静的な場合と同じであるが，その特異場の強度を表 す応力拡大係数 $K$ が時間 $t$ の関数となる点で静的と 異なっている。

1962 年 Baker ${ }^{6}$ は半無限き裂に対して入射波がき裂 に到達してからの時間を $t$ とすると, 動的応力拡大係 
数 $K(t)$ はゼロから $\sqrt{t}$ に比例して増大することを示 した. 1971 年 Thau ら”は無限板中の有限長さのき裂 にステップ関数状の応力波が入射するときの動的応力 拡大係数がゼ口から $\sqrt{t}$ に比例して增大した後，き 裂の他端で散乱された膨張波・せん断波の到達による 影響を順に受け、さらに Rayleigh 波の到達した瞬間 に最大值をとって折れ曲がることを明らかにした。 1972 年 $\operatorname{Sih} 5^{8)}$ はこの問題の動的応力搪大係数 $K(t)$ が最大值をとった後，静的な $K$ に振動を伴いながら 近づくことを示した。

破壊じん性試験片に衝擊荷重が作用したときの動的 応力拡大係数 $K(t)$ を解析的に求めることは一般に不 可能であるが，数值解を得ることは可能である．中央 き裂を有する帯板の両端面にステップ関数状の引張応 力を作用させた場合について，1975 年 Chen" は差分 法により $K(t)$ を計算し，1977 年 Aberson ら ${ }^{100}$ は特 異要素を用いた有限要素法 (FEM) で求めてChen の 結果と比較した．同様な問題について 1978 年 Aoki

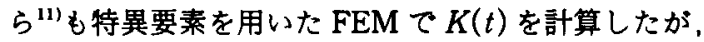
1980 年岸本ら ${ }^{122}$ は $\hat{J}$ 樌分から $K(t)$ を評価する方法 を提案し，特異要素を用いない FEM でも高精度な計 算ができることを示した．また，1981 年和田ら ${ }^{131}$ は 合力比定数法を提案し，特異要素を用いないFEM で 計算したき裂先端要素の応力 $\sigma$ と応力拡大係数 $K$ の 比例関係によって Aoki ら ${ }^{11)} の$ 問題の $K(t)$ を簡便に 評価できることを示した。このような特異要素を用い ないFEMで $K(t)$ を求める方法は，衝撃破壊じん性 試験における $K(t)$ を計算する場合やNIKE 3 D など 既成の汎用構造解析コードによって実構造物に対する $K(t)$ を評価する場合に容易に利用することができ る。

本研究の目的は，衛撃破壊じん性 $K_{\mathrm{Id}}$ を正確に測定 するための試験において重要な問題でるる動的応力拡 大係数 $K(t)$ の正確な計算方法を開発することにあ る。著者ら ${ }^{14)}$ はすてに $K(t)$ を正しく求めるため静的 な評価式から計算した $K^{\text {stat }}$ に対する動的補正係数 $a(t)$ の導入を提案し，試験片のき裂先端近傍の動的 ひずみの测定值と静的な値の比から衝撃応答関数 $\alpha(t)=K(t) / K^{\text {stat }}$ を求めて正確な $K_{1 \mathrm{~d}}$ の決定を試みて きた ${ }^{15)}$ 本論文では，これまでの実験的な $\alpha(t)$ の評 価において示した考え方 ${ }^{16)}$ FEMによる解析的な街 擊応答関数 $\alpha(t)$ の評価に応用することを試みた。こ の考え方とは，き裂先端近傍の開口変位 (COD) と応 力拉大係数の比例関係に着目して CODの動的な解析 值と静的な值の比をとることにより徨撃応答関数 $\alpha(t)$ を決定する方法であり，特異要素を用いない有
限要素法でも高精度に $\alpha(t)$ を計算することができる。 さらに，任意の負荷波形に対する衝擊応答関数 $\alpha(t)$ は，ステップ状の波形に対するステップ応答関数 $h(t)$ を時間領域に関して重ね合わせることによって 求められる。したがって，FEM を用いて $h(t)$ を解析 し，実測波形に対して $h(t)$ を重和合わせて $\alpha(t)$ を求 め, $K(t)=\alpha(t) \cdot K^{\text {stat }}$ 上り動的応力拡大係数を効率よ く評価することができる。このため，著者らは $h(t)$ を解析する FEM プログラムを開発し，その計算精度 をThau らの解析解と比較することにより確かめ, 上 記のような手順で動的応力拡大係数 $K(t)$ を計算する 方法の有用性と長所を実際の衝撃破壊じん性試験の典 型例であるCostin らの実験を数值シミュレーション することによって示した。

2. ホプキンソン棒法による衝撃引張破塤試験に おける勚的応力拡大係数 $K(t)$ の評価方法

材料の衝擊破壊じん性 $K_{\mathrm{Id}}$ を測定するため，著者ら は，ホプキンソン棒法を応用した縦衝擊破壊試駼にお ける動的応力拡大係数 $K(t)$ を

$$
K(t)=\alpha(t) \cdot K^{\text {stat }}
$$

で評価することを提案した ${ }^{14)}$.ここに， $\alpha(t)$ は動的な 効果を補正するために導入した衝擊応答関数である。 また， $K^{\text {stat }}$ は静的な評価式に動的な公称応力 $\sigma$ を代 入して求まる応力拡大係数であり，この静的な評価式 はハンドブッグ7などに次の形で整理されている．

$$
K^{\text {stat }}=\sigma \sqrt{\pi a} f(a / W)
$$

ここに，aはき裂長さ， $f(a / W)$ は試験片の形状(た とえば $W$ がき裂部の板幅を表す）による補正係数て ある。

動的な公称応力 $\sigma$ は，負荷時間 $t$ が十分長くなり， 動的な奻果が無視できる状態に対して $\alpha(t)=1$ となる ように静的な公称応力 $\sigma$ も包含する定義を与えるべ きである．そこで，動的・静的の区別なく公称沁力 0 を「き裂面の位置にき裂がない場合に作用する応力」 と定義した。この公称応力 $\sigma$ は，ホプキンソン棒方 式の衝慗破垻試験の場合，き裂に負荷される入射店力 $\sigma$ ，等しく，一方，静的な場合「無限遠方の一様広力] で定義される応力 $\sigma$ と同じ值となる．

ステップ関数状の入射応力 $\sigma_{1}$ がき裂に入射した場 合，(2)式で与えられる $K^{\text {stat }}$ は波頭の到達と同時に 静的な值となるが， $K(t)$ はゼ口から $\sqrt{t} に$ 比例して 増大した後 $K^{\text {stat }}$ に近づく．この場合の(1)式の $a(t)$ をとくにステップ答関数として $h(t)$ と記すと， $h(t)$ はゼロから立ち上がって1に収束するような時 間変化を示す。 
実際の入射応力 $\sigma_{1}(t)$ は，Costin $5^{3)}$ の周切欠丸 棒試臨片や Homma ら ${ }^{18)}$ の片側切欠試験片のように 長い試験片中の応力波の伝播がき裂部を除いてほほ浔一 次元波動伝播理論によって解秎できることを用いて， ホブキンソン棒法により計測できる。この試験片断面 内で浪浑一様な入射応力 $\sigma_{1}(t)$ の実測波形に対する衝 拲応答関数 $\alpha(t)$ は，次のステップ応答関数 $h(t)$ のた たみ込み積分により重ね合わせを行って求められる.

$$
\alpha(t)=\frac{1}{\sigma_{1}(t)} \int_{0}^{t} h(t-\tau) \cdot \dot{\sigma}_{1}(\tau) d \tau
$$

$こ こ に, \dot{\sigma}_{1}(t)$ は実測された入射応力 $\sigma_{1}(t)$ の時間微 分をとった応力速度である．

ステップ応答関数 $h(t)$ の数值解を用いて ( 3 )式か らホプキンソン棒法によって剆定される入射応力 $\sigma$ 汶対する街擊応答関数 $\alpha(t)$ を効率よく計算できるこ とは，衝擊破壊じん性試験における動的応力拡大係数 $K(t)$ を簡便に評価する上で有用である。このために 必要なステップ応答関数 $h(t)$ の数值解は, 次に述へ る有限要素法 (FEM) を用いた解析方法で求められ ろ.

FEMでき裂先端のような特異応力場を有する問題 の高精度な数值解を得るためには，一般に特別な工夫 が必要である.き裂先端近傍の開口変位 (COD) と応 力㹡大係数 $K$ との間には動的な場合も静的な場合と 同じ比例関係が存在する。したがって，ここでは特異 要素を用いないFEMによってき裂先端近くの複数個 の節点それそれれに対して計算された CODの動的な解 析値と静的な值の比から，ステップ応答関数 $h(t)$ を 推定することを試みた。

CODの動的な解析值を得るために FEMによって 次の弾性体の微小変形に対する運動方程式を New. mark の $\beta$ 法を用いて解く.

$$
[K]\{\Delta u\}+[M]\{\Delta \ddot{u}\}=\{\Delta F\}
$$

また，COD の静的な解析值を得るために FEM て

$$
[K]\{\Delta u\}=\{\Delta F\}
$$

の平衡方程式も解く 。ここに, [K]は剛性マトリック

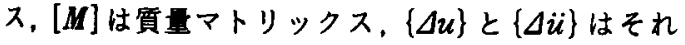
ぞれ $\{\Delta F\}$ の節点外力増分ベクトルに応した節点変位 と節点加速度增分へクトルである。

Newmark の $\beta$ 法を用いて状態 $n-1$ から $\Delta t$ 時間 後の状態 $n$ の変位 $u_{n}$ および速度 $\dot{u}_{n}$ は

$$
\begin{aligned}
u_{n}= & u_{n-1}+\Delta t \cdot \dot{u}_{n-1}+\left(\frac{1}{2}-\beta\right) \Delta t^{2} \cdot \ddot{u}_{n-1} \\
& +\beta \Delta t^{2} \cdot \ddot{u}_{n} \\
\dot{u}_{n}= & \dot{u}_{n-1}+\frac{\Delta t}{2} \ddot{u}_{n-1}+\frac{\Delta t}{2} \ddot{u}_{n}
\end{aligned}
$$

と与えられる。これを応用して(4)式を変形すると，

$$
\begin{aligned}
& \left([\boldsymbol{K}]+\frac{1}{\beta \Delta t^{2}}[\boldsymbol{M}]\right)\{\Delta u\} \\
& \quad=\{\Delta F\}+[\boldsymbol{M}]\left(\frac{\left\{\ddot{u}_{n-1}\right\}}{2 \beta}+\frac{\left\{\dot{u}_{n-1}\right\}}{\beta \cdot \Delta t}\right) \\
& \left\{u_{n}\right]=\left\{u_{n-1}\right\}+\{\Delta u\} \\
& \left\{\dot{u}_{n}\right\}=\left\{\dot{u}_{n-1}\right\}+\{\Delta \dot{u}\} \\
& \{\Delta \dot{u}\}=\frac{\{\Delta u\}}{2 \beta \cdot \Delta t}-\frac{\left\{\dot{u}_{n-1}\right\}}{2 \beta}+\left(1-\frac{1}{4 \beta}\right) \cdot \Delta t \cdot\left\{\ddot{u}_{n-1}\right\} \\
& \left\{\ddot{u}_{n}\right\}=\left\{\ddot{u}_{n-1}\right\}+\{\Delta \ddot{u}\} \\
& \{\Delta \ddot{u}\}=\frac{\{\Delta u\}}{\beta \cdot \Delta t^{2}}-\frac{\left\{\dot{u}_{n-1}\right\}}{\beta \cdot \Delta t}-\frac{\left\{\ddot{u}_{n-1}\right\}}{2 \beta}
\end{aligned}
$$

の $\{\Delta u\}$ を末知数とする連立一次方程式が得られる. (7)式は $[\boldsymbol{M}]$ をゼロマトリックスで置き換えると (5)式に一致するので, 動的 COD と静的 COD が同 一プログラムで解析できる. 同じ要素分割のモデルを 用い, 同一のプログラムによって解析した動的 COD と静的 COD の比をとると，空間の有限要素による離 散化近似の影響が相殺されるため，比較的粗い要素分 割でも高精度な $h(t)$ の数值解を推定しうる.

ステップ応答関数 $h(t)$ を解析する場合, 初期条件 を入力するための工夫も必要である.（7)式の $\{\Delta F\}$ にステップ関数状の外力 $\left\{F_{0}\right\}$ をたんに入力しただけ では未知数である変位增分 $\{\Delta u\}$ が初期において正解 より小さな值として計算される．この問題を解決する ために $\left\{F_{0}\right\} に$ 相当する初速度 $\left\{\dot{u}_{0}\right\}$ 同時に入力して ステップ応答関数 $h(t)$ の計算精度を向上させた

ステップ関数状の入射波に対して，変位は波頭を横

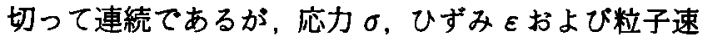
度 $v$ は不連続となる。このとき法線ぺクトル $\{n\} の$ 波頭面上に作用する表面力ベクトル $[\sigma]\{n\}$ と粒子速 度へクトル $\{v\} の$ 間には，次の跳躍条件式が成り立 ว.

$$
[\sigma]\{n\}+\rho c\{v\}=0
$$

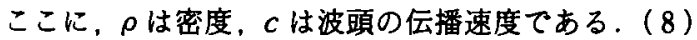
式から算出されたステップ状の入射応力 $\sigma_{1}$ に相当す る粒子速度 $v_{1}$ を外力境界節点の初速度 $\left\{\dot{u}_{0}\right\}$ として与 えると，のに相当する初期外力 $F_{0}$ が作用したときと 同様なステップ応答を計算できる。

ステップ応答関数 $h(t)$ の解析において安定した時 間積分を実行するため，時間增分 $\Delta t$ は節点間最小距 離 $l$ を膨張波 $c_{1}$ が伝播するのに要する時間 $l / c_{1}$ 以下 にとって，Newmark の係数 $\beta$ は $1 / 4$ を用いてい る.

\section{3. ステップ応答閧数 $h(t)$ の計算精度の検討}

ステップ応答関数 $h(t)$ を特異要素を用いない FEM で評価する方法の計算精度を検討するため，Thau ら》によって解析解の示された問題を著者らの FEM 


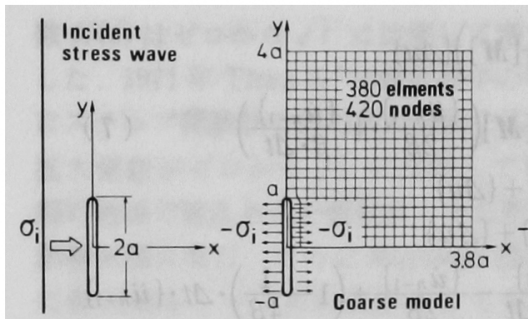

(a)

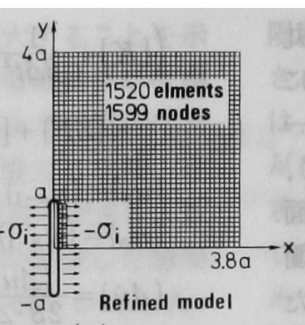

c)

第 1 図き裂へ垂直に応力波 $\sigma_{1}$ が入射するThauら”の問 題と FEM 解析に用いた要索分割

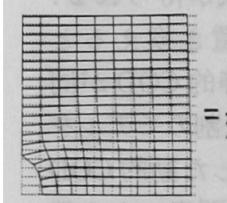

(a) Average

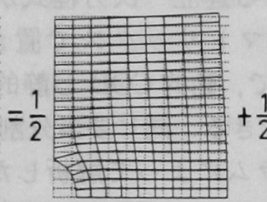

(b) Free

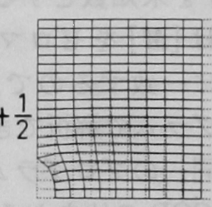

(c) Fixed

第 2 図 静的 FEM による変位の解析結果

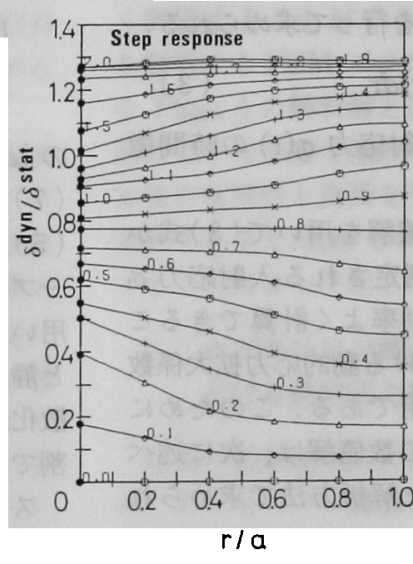

(a) Coarse model
3 図動的FEMによる変位の解析結果
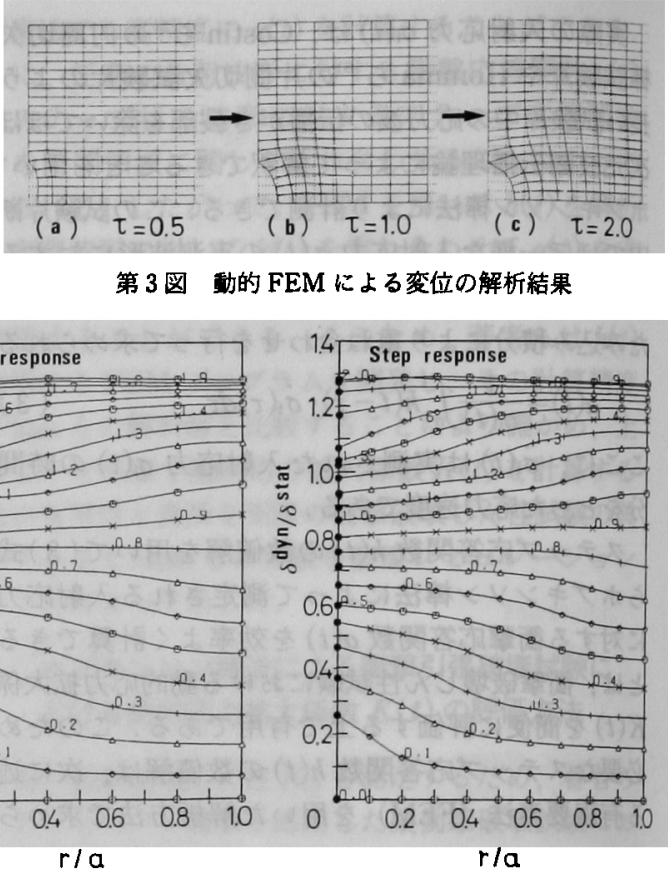

(b) Refined model
プログラムを用いて求め, $h(t)$ の数值解と解析解の 比較を行った。第 1 図(a)にThauら"の解析した問 題を示す，長さ $2 a$ のき裂の中央を原点 0 とする直角 座標系 $\mathrm{O}-x y$ において， $x$ 方向に速度 $c_{1}$ で伝播する ステッブ関数状の跀張波 $\sigma_{1} か ゙ y$ 軸上にあるき裂に入 射する場合の動的応力拡大係数 $K(t)$ は，ステップ関 数状の表面力 に对する $K(t)$ と等しい，そこで， $x$ 軸と $y$ 軸につい て対称性をもつ散乱応力場を FEMにより解析し、ス テップ応答関数 $h(t)=K(t) / K^{\text {stat }}$ を求めた.

要素分割の粗さが計算精度に及隹す影響を調べるた め、第 1 図(b)と(c)の平面ひずみ 4 節点アイソパラ メトリック要素の一辺がそれぞれ $a / 5$ と $a / 10$ である モデルを用いて(8)式から初期条件を与え $h(t)$ を計 算した。 また，ステッフ関数状の外力に相当する初速 度 $v_{1} を(8)$ 式で計算して初期条件として入力したこ とによる $h(t)$ の計算精度の向上について調へるるめ $に$ ，第 1 図 $(b)$ の要素分割が粗く時間増分 $\Delta t$ の長い モデルを用いて初速度を入力しない FEM 解析も追加 して実施した．モデル化においては， $x$ 軸と $y$ 軸に 関する散乱応力場の対称性の他に，き裂面で発生した 散乱波が $x=3.8 a$ と $y=4 a$ に設けた固定境界で反射 された後再びき裂先端へ到達するまでの $t<6 a / c_{1}$ の時 間䇺囲に対して無限体中と同じ動的 COD を計算でき る点も考虑した。

第 2 図は静的 FEM 解析結果の変位を実際より拡大 して示した変形図である．第 2 図 (a)が無限体中のき
第 4 図裂開口変位の的と静的の比の解析結果

裂にーの㙏表面力を静的に作用させた場合の変形を 表す， $x=3.8 a$ と $y=4 a$ の境界で囲まれた有限の大 きさのモデルを用いて無限体中の変位分布を計算する ため，第 2 図(b)に示されるようなモデル周囲が自由 表面である場合の変位分布と第 2 図(c)のような固定 境界である場合の変位分布とを FEM で求めて平均を とったものが第 2 図(a)である．また，第 2 図(a)に 示されたき裂面の各節点の $x$ 方向変位が静的 $\mathrm{COD}$ と なる。

第 3 図は動的 FEM 解析結果を第 2 図と同様に変位 を拡大して示した変形図である。ここで，Thauらと 同様にき裂長さ $2 a$ を速度 $c_{1}$ の膨張波が伝播するのに 要する時間 $2 a / c_{1}$ で無次元化した時間 $\tau$ を用いて $0.5,1.0,2.0$ の変形をそれぞれ第 3 図の(a)，(b)， (c)に示した. 動的解析で得られたき裂面各節点の 方向変位である動的 $\operatorname{COD}\left(\delta^{\mathrm{dyn}}\right)$ と第 2 図 (a)に示さ れた静的 $\operatorname{COD}\left(\delta^{\text {stat }}\right)$ の比が，時間 $\tau$ とともにゼ口か ら増大する様子を第 4 図に示す．横軸の rla はき裂先 端からの距離 $r$ を $a$ で無元次元化した值でり，図 中の数字はそれぞれの時間 $\tau$ を表す。き裂先端 $r=0$ にプロットした黒丸は，き裂から第 1 近接わよび第2 近接の位置にある節点の $\delta^{\mathrm{dyn}} / \delta^{\mathrm{stat}}$ から直線外挿した 值である. 要素分割の異なる第 4 図(a)と(b)の禹方 で、き裂の画端で散乱された䏽張波，せん断波およひ 


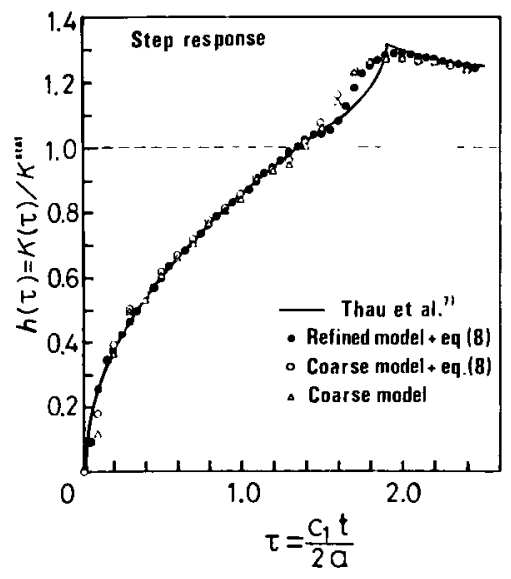

第 5 図 ステップ応答関数 $h(\tau)$ の計算結果

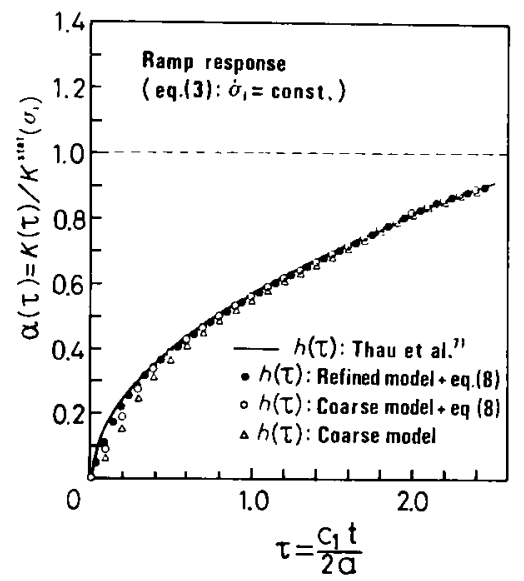

第 6 図 $h(\tau)$ の重合せによる $\dot{\sigma}_{1} か ゙ 一$ 定な入射波に対する ランプ応答関数 $\alpha(\tau)$ の計算結果
Rayleigh 波がそれぞれき裂中心 $r=a$ において交差 する時間 $\tau=0.5, \tau=0.866$ および $\tau=0.942$ の前後の $\delta^{\mathrm{dyn}} / \delta^{\text {slat }}$ は，rに对してほほ一定值をとることがわ かる.き裂先端近くの $\delta^{\text {dyn }} / \delta^{\text {stat }}$ がほほ定値を示す ということは，その動的な変位場の $r に$ 対する分布 形が静的な場合とほほ一致していることを表し。 COD と応力㹡大係数の比例関係によって $r=0$ の

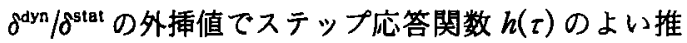
定值を与えることができる。

第 5 図に $\delta^{\mathrm{dyn}} / \delta^{\mathrm{stat}}$ をき裂先端に外挿して求めたス テップ応答関数 $h(\tau)$ の時間変化を示す. 三角印は粗

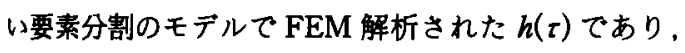
白丸印と黒丸印はそれぞれ粗い分割と細かい分割のモ テルで(8)式からステップ関数状の外力に相当する初

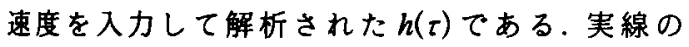
Thauらによって示された $h(\tau)$ の解析解と比較する と，同し粗い分割のモデルを用いても初速度を入力し た白丸印のほうが入力しない三角印より立上りの 0.1 でただちに解析解に近づくことから，(8)式で初 期条件を考慮する方法による $h(\tau)$ の計算精度向上が 碓かめられた。また，第 5 図でFEMによる $h(\tau)$ の 数值解は，三つとも $0.4 \leqq \tau \leqq 1.2$ の時間篹囲内で実線 の解析解とよく一致した，この時間籍囲は，第 4 図に おいてき裂先端近くの $\delta^{\mathrm{dyn}} / \delta^{\text {stat }}$ の值が $と に$ 対してほ は一定值を示す時間領域であることがかかる。さら k, き裂の先端 $r=2 a$ で散乱された Rayleigh 波の到 達により $h(\tau)$ の解析解が折れ曲がる時間 $\tau=1.884$ の 直前で, $h(\tau)$ の数值解に要素分割の細粗による影艟 か現れている.

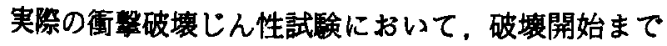
の負荷波形はステップ関数状でなく，時間 $t$ に比例し
て増加するランプ状の波形に近いそこで、衝撃破壊 じん性試験における衝撃応答関数 $\alpha(\tau)$ の計算精度を 検討するため $(3)$ 式を用いて第 5 図のステッフ応答関 数 $h(\tau)$ からランプ応答関数 $\alpha(\tau)$ を求めた.

第 6 図に $h(\tau)$ の解析解から計算されたランプ応答 関数 $\alpha(\tau)$ を実線 $\tau, h(\tau)$ の数值解から求めた $\alpha(\tau)$ を第 5 図と同じ記号で示す．黑丸印と白丸印の $\alpha(\tau)$ は， $\tau=1.0$ 以後で実線と $2 \%$ の誤差範囲内で一致し た。しかし，三角印で示された初速度を入力しない場 合の $h(\tau)$ から算出された $\alpha(\tau)$ は，誤差 $2 \%$ 以内にな るのが $\tau=1.7$ と初速度を入力した場合の $h(\tau)$ を用い た $\alpha(\tau)$ に比へて晴くなっている．以上のことから， 比較的粗い要素分割でステップ応答関数 $h(\tau)$ を評価 しても，第6図の黒丸印と白丸印の $\alpha(\tau)$ のうに衝 擊応答関数を精度よく計算できることがわかる。

\section{4. ホブキンソン棒法による衙撃引張破壊試験に おける動的応力搪大係数 $K(t)$ の計算例}

ホプキンソン棒法による衞擊引張破壊試験の典型例 である Costin ら ${ }^{33}$ 実験で報告された入射応力の実測 波形に対する重擊応関数 $\alpha(t)$ を計算し, 動的応力 拡大係数 $K(t)$ を評価するとともに，静的な応力搪大 係数の評価式に基づいてCostin らが衝撃破壊じん性 を測定した結果の信頼性について述べる。

Costinらが用いた円周切久丸棒試験片において， 断面内で一様な応力分布の引張応力波 $\sigma_{1}$ がき裂に入 射する第 7 図(a)の応力場は，き裂面に一の, の表面 力を作用させた第 7 図(b)の散乱応力場とき裂のない 丸棒に $\sigma_{1}$ が入射する第 7 図(c)の応力場の重小合わ せに等しい. 第 7 図(c)の応力場には特異性がないの $\tau$, 第 7 図 (a)の $K(t)$ は第 7 図(b) の散乱応力場の 


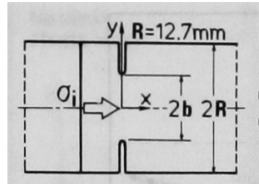

(a)

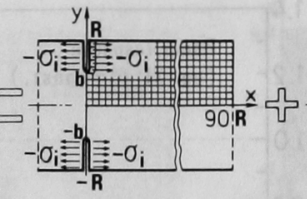

(b)

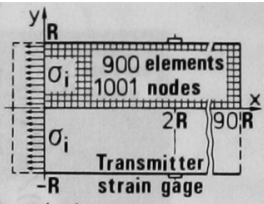

(c)

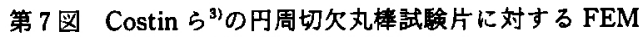
解析の要素分割上境界条件

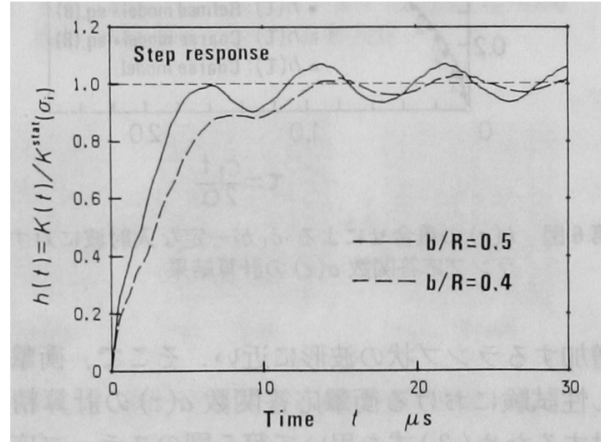

第 8 図 円周切久丸棒試験片のステップ応答関数 $h(t)$

解析から求めることができる．散乱応力場の対称性を 利用すると第 7 図(b)に示した領域を一辺が $R / 10(R$ は丸棒の半径)である 4 節点軸対称アイソパラメトリ ック要素で分割し、ステップ応答関数 $h(t)$ の数值解 を FEM を用いて評価できる．第 8 図にき裂部 ligament 半径 $b$ が $0.5 R$ おるよひ $0.4 R$ に対する $h(t)$ の 計算結果を示す. 図から $h(t)$ がき裂長さ $a=R-b$ の 影锌を受け， $a$ の長い $b / R=0.4$ のほうが 0.5 に対す る結果より遅れて立ち上がることがわかる。

Costin らは，き裂から 1 直径 $(25.4 \mathrm{~mm})$ 離れた位 置に貼ったひずみゲージで測定した透過応力 $\sigma_{\mathrm{t}}$ から 衝擊荷重 $P(t)$ を計算し，これを静的な応力搪大係数 の評価式に代入して $K(t)$ を評価した. Costin らが測 定した透過応力 $\sigma_{\mathrm{t}}$ は，第 7 図(b)のモテルで得られ た散乱応力場と同じ要素分割のモデルに対して第 7 図 （c）の境界条件を与えて計算した入射応力場を FEM て解析し，両応力場を重姶わせた第 7 図 (a)を計算 することによって求められる.ステップ状の入射応力 のが作用する場合， $b / R=0.5$ および 0.4 に対する透 過応力 $\sigma_{t}$ のステップ応答 $\sigma_{t} / \sigma_{1}$ は，それそれ第 9 図の 実線と破線の時間変化を示す. 第 8 図の $h(t)$ と第 9 図の $\sigma_{\mathrm{t}} / \sigma_{1}$ のステップ応答を比べる，立上がり部分 はほほ同じで $\sigma_{t} / \sigma_{1}$ のほうが $h(t) よ り$ 速く 1 に収束す る傾向が表れている.

Costin らは，SAE 1020 冷間圧延龬の試駼片番号 C-9 の衙撃試験結果を典型的な実匼例として示してい

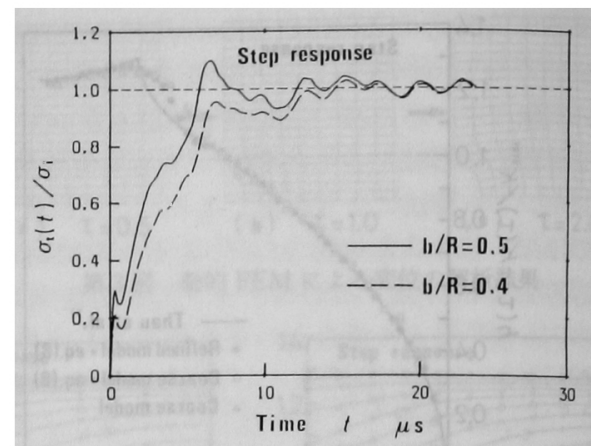

第 9 図 ステップ応力波 $\sigma_{1}$ が入射したときの無次元化透 過応力 $\sigma_{t}(t) / \sigma_{1}$ の時間沁答

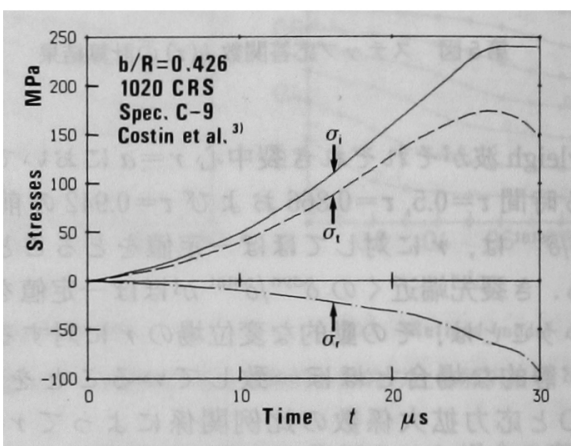

第 10 図 Costin 5 ${ }^{3)}$ の重擊破壤試験における典型的な入 射応力 $\sigma_{1}$, 透過応力 $\sigma_{\mathrm{t}}$, 反射応力 $\sigma_{\mathrm{r}}$ 波形

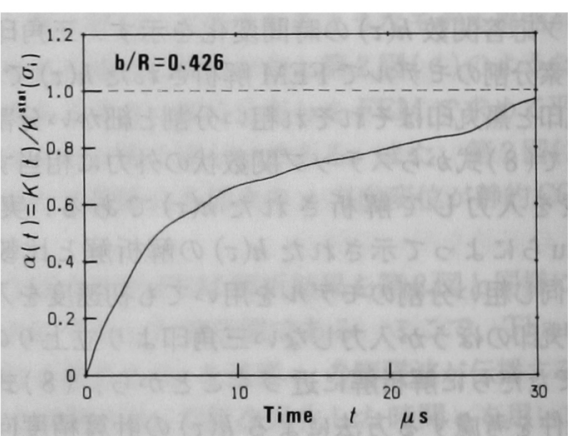

第 11 図 典型的な入射応力 $\sigma_{1}$ の実測波形に対する行䇣店 答関数 $\alpha(t)$ の計算結果

る.この試験片の ligament 半径 $b$ は $5.41 \mathrm{~mm}$ と記 されていたので $b / R=0.426$ となる.オシロスコーフ の写真で示された入射ひずみゲージと透過ひずみゲー ジの典型的な出力波形から入射応力 $\sigma_{1}$, 反射応力 $\sigma_{r}$, 透過応力 $\sigma_{\mathrm{t}}$ の時間変化を読み取った結果を第 10 図炕 示す.

第 10 図の入射応力 $\sigma$ に対する動的応力㹡大保数 $K(t)$ (1) 式で計算するのに必要な衙繋応答関数 


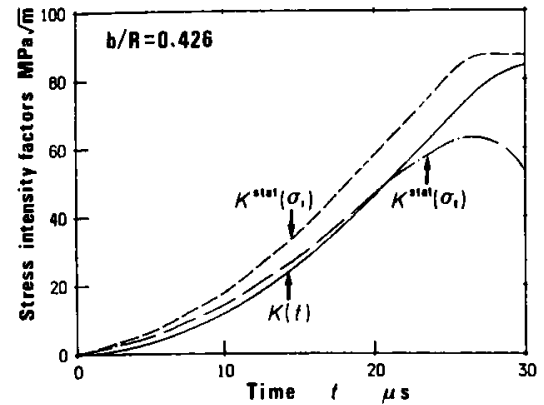

第 12 図動的応力拡大係数 $K(t)$ の計算結果および静的 な評価式に入射応力 $\sigma_{1}$ と透過応力 $\sigma_{\mathrm{t}}$ を代入し て求めた応力㹡大係数 $K^{\text {stat }}$ の時間変化

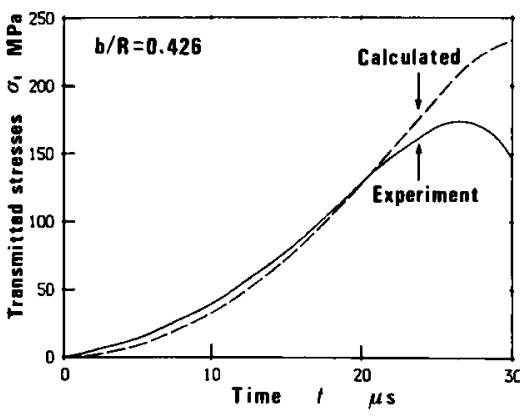

第 13 図透過応力 $\sigma_{\mathrm{l}}$ の実験て測定された波形とき致進展 のない条件で計算された波形の比较

$a(t)$ は、第 8 図の $b / R=0.5$ と 0.4 の結果から実測值 $b / R=0.426$ に対する $h(t)$ を内挿で求めた後, $(3)$ 式 により第 11 図のように推定できる。（2）式の応力拡 大係数の静的な評価式は $b / R=0.426$ の円周切欠丸棒 試験片に対して具体的に

$$
K^{\text {stat }}(\sigma) \simeq 0.484 \cdot \sigma \sqrt{\pi b} \cdot\left(\frac{R}{b}\right)^{2}
$$

で与えられる．第 12 図の破線は，(9)式の公称応力 $\sigma k$ 第 10 図の入射応力 $\sigma$ 代入して得られる $K^{\text {stat }}\left(\sigma_{1}\right)$ で，実線は $K^{\text {stat }}\left(\sigma_{1}\right)$ に第 11 図の $\alpha(t)$ を掛け て求めた動的応力拡大係数 $K(t)$ てある。. また，一点 鎖線はCostin らが用いた $(9)$ 式の公称応力 $\sigma に$ 透過 忘力 $\sigma_{\mathrm{t}}$ を代入して計算した $K^{\text {stat }}\left(\sigma_{\mathrm{t}}\right)$ である．第 12 図 より時間 $t \leqq 21 \mu \mathrm{s}$ において $K^{\text {stat }}\left(\sigma_{t}\right)$ は動的応力拡大 保数 $K(t)$ のよい推定值を与えることがわかる.

一方，第 9 図の透過応力のステップ応答 $\sigma_{t} / \sigma_{t}$ をb/ $R=0.426$ に対して内㨉し，第 10 図の入射応力 $\sigma$ の実 測波形に対して重ね合わせを行うと第 13 図の破線で 示される透過応力 $\sigma_{\mathrm{t}}$ の計算波形が求められる.これ を第 13 図の実線で示される $\sigma_{\mathrm{t}}$ の実測波形と比較する と，t>21 $\mu \mathrm{s}$ で明らかに異なることがかかる. 計算
波形はき裂長さが一定であることと弾性範囲内である ことを仮定している。へき開ファセットを破面に呈す るようなぜい性破壊を起こす場合には，第 13 図に示 される $\sigma_{\mathrm{t}}$ の計算波形と実測波形の差はき裂進展が原 因であり．破壇開始時間 $t_{c}$ をこれらの差の現われ始 めた点で決定することが可能である．しかし，Costin らの供試材であるSAE 1020 冷間圧延鋼の場合 $\sigma_{\mathrm{t}}$ の 計算波形と実測波形の差はき裂進展によるのか，き裂 先端での塑性変形が原因であるのかが不明である。 SAE 1020 冷間圧延鋼の降伏応力はひずみ速度依存性 が大きく衙撃破壊じん性 $K_{\mathrm{Id}}$ 試験において生じるき裂 先端での塑性域は静的な $K_{\mathrm{Ic}}$ 試験時に比べ相当小さく なる。したがって，CostinらはSAE 1020 冷間压延 鋼の静的な $K_{\mathrm{Ic}}$ は塑性変形のため測定できなかった が、衝撃破境しん性 $K_{\mathrm{Id}}$ は塑性域補正を行って 70.6 $\mathrm{MPa} \sqrt{\mathrm{m}}$ と湘定している．第 13 図から破壊開始時間 $t_{\mathrm{c}}$ は $21 \mu \mathrm{s}$ から $25 \mu \mathrm{s}$ までの範囲にあって，塑性域補 正をしない $K_{\mathrm{ld}}$ は第 12 図の実線より $58 \sim 69 \mathrm{MPa} \sqrt{\mathrm{m}}$ となる.この実験の場合正確なき裂進展開始時間 $t_{c}$ の決定のために電位差法など他の検出方法が必要であ つたが，動的応力拡大係数 $K(t)$ を透過応力 $\sigma_{\mathrm{l}}$ の実湘 值から静的な評価式を用いて評価する方法は，第 12 図の $K(t)$ の実線と $K^{\text {stat }}\left(\sigma_{t}\right)$ の一点銷線のよい対応か ら Costin らの試験片形状と透過ゲージ位置に対して， ほほ正確な破壊じん性を測定できることがわかる．

\section{5. 結㻅}

本研究では，正確な衙摮破壊じん性 $K_{\mathrm{ld}}$ の測定に不 可欠な動的応力拡大係数 $K(t)$ の数值計算の方法を提 案した，その特長は次のようにまとめられる。

(1) 動的応力拡大係数は $K(t)=\alpha(t) \cdot K^{\text {stat }}$ の上 うに静的な応力拡大係数の評価式から求まる $K^{\text {stat }} に$ 衝擊応答関数 $\alpha(t)$ の動的補正を行って評価できる。

（2）衛撃応答関数は入射応力 $\sigma_{1} の$ 実測波形に対 ᄂ.

$$
\alpha(t)=\frac{1}{\sigma_{1}(t)} \int_{0}^{t} h(t-\tau) \cdot \dot{\sigma}_{1}(\tau) d \tau
$$

の式を用いてステップ応答関数 $h(t)$ を重ね合わせる ことにより正確に計算される。

(3) ステップ応答関数 $h(t)$ は特異要菜を用いな いFEM 解析によって求められたき裂開口変位の動的 と静的の比から推定できる.その精度は Thau らの解 析解と比較検討した結果から，比較的粗い要素分割て も $K(t)$ の計算に対して十分であることがわかった。

実際の衝擊破壊じん性試験の典型例である Costin らの実験の数值シミュレーションを本計算法を用いて 行った結果， $K(t)$ とCostin らが透過荷重から静的公 
式により評価した応力拡大係数がほほ一致することが 示されたので, Costin らの求めた $K_{\mathrm{Id}}$ は信頼できる ことがわかった．また，透過応力 $\sigma$ の実測波形とシ ミュレーションで求めた $\sigma_{\mathrm{t}}$ の計算波形はき裂進展が ないと考えられる時間範囲でよく一致したことから， ぜい性材料の破壊開始点を $\sigma_{\mathrm{t}}$ の計算と実測の両波形 の差が現れ始めた点で決定することも可能である．

最後に本研究を進めるにあたり，文部省科学研究費 補助金 $(58550045 ， 59750043 ， 61050038)$ の援助を受 けた，また，FEM 解析には大阪大学大型計算機セン ターのコンピュータ $(\mathrm{ACOS} 1000)$ を用いた。記して 謝意を表する。

\section{参考文献}

1) Standard Test Method for Plane-Strain Fracture Toughness of Metallic Materials, American National Standard ASTM E399-83, 1983, pp. 518-553.

2) Server, W. L. : Impact Three-Point Bend Testing for Notched and Precracked Specimens, J. Testing Evaluation, 6 (1978), pp. 29-34.

3) Costin, L. S., Duffy, J. and Freund, L. B. : Fracture Initia tion in Metals under Stress Wave Loading Conditions, ASTM STP 627, 1977, pp. 301-318.

4) Kishimoto, K., Aoki, S. and Sakata, M.: Simple Formula for Dynamic Stress Intensity Factor of Precracked Charpy Specimen, Engng. Fract. Mech., 13 (1980), pp. 501-508.

5）岸田敬三、横山 隆，中野元博、塚本秀郎：動的破壊じん 性 $K_{1 \mathrm{~d}}$ 決定のための新しい衡擊 3 点曲げ試験法，第二回材 料の衝擊問題シンボジウム前刷集，1987，pp. 117-120.

6) Baker, B. R. : Dynamic Stress Created by a Moving Crack, Trans. ASME, J. Appl. Mech., 29 (1962), pp. 449454.
7) Thau, S. A. and Lu, T. H. : Transient Stress Intensity Factors for a Finite Crack in an Elastic Solid Caused by a Dilatational Wave, Int. J. Solids Struct., 7 (1971), pp. 731-750.

8) Sih, G. C., Embley, G. T. and Ravera, R. S.: Impact Response of a Finite Crack in Plane Extension, Int. J. Solids Struct., 8 (1972), pp. 977-993.

9) Chen, Y.M.: Numerical Computation of Dynamic Stress Intensity Factors by a Lagrangian Finite Difference Method, Engng. Fract. Mech., 7 (1975), pp. 653-660.

10) Aberson, J. A., Anderson, J.M. and King, W. W.: Dynamic Analysis of Cracked Structures Using Singularity Finite Elements, Elastodynamic Crack Problems, ed. by Sih, G. C., Noordhoff, Leyden, 1977, Chap. 5.

11) Aoki, S., Kishimoto, K., Kondo, H. and Sakata, M. Elastodynamic Analysis of Crack by Finite Element Method Using Singular Element, Int. J. Fract., 14 (1978), pp. $59-68$

12）岸本喜久雄，青木 繁，大里豊彦，坂田 勝：J积分を用 いた動的応力拡大係数の有限要素解析，日本機械学会諭文 集 (A 編)，46(1980)，pp. 584-589.

13）和田 均，高木 豊，西村 虽：有限要素法に上了応力摭 大係数の一計算法とその動的問題への応用，日本機械学会 論文集， 47 (1981)，pp. 501-511.

14）岸田敬三，中川㥶治：スプリットホプキンソン棒法による 動的破壤じん性の測定，材料，32 (1983)，pp. 1096-1101.

15) Kishida, K., Yokoyama, T. and Nakano, M. : Measurement of Dynamic Fracture Toughness Based on the Split Hopkinson Bar Technique, Inst. Phys. Conf. Ser. No. 70, 1984, pp. 221-228.

16）中野元博，岸田敬三：衝擊荷重を受ける静止き裂に対する 動的応力应大係数の決定について，日本航空宇宙学会第 16 期年会講演会講演集、1985，pp. 196-197.

17) Sih, G. C. (ed.) : Handbook of Stress Intensity Factors, Inst. Fract. and Solid Mech., Lehigh University, 1974.

18) Homma, H. and Shockey, D. A. : Response of Cracks in Structural Materials to Short Pulse Loads, J. Mech. Phys. Solids, 31 (1983), pp. 261-279. 